\title{
Comparison of the Paired Compound Words in Russian and Chinese
}

\author{
Xiaoge $\mathrm{Li}^{*}$ \\ Peoples' Friendship University of Russia - RUDN University, 6, Miklukho-Maklay str., Moscow, Russia, 117198 \\ *Corresponding author.Email: E-Mail: lixiaoge89@mail.ru
}

\begin{abstract}
The article offers the definition and types of the paired compound words in Russian and Chinese, compares different types of the paired compound words in terms of their essential parameters. The purpose of the research is to present types of the paired compound words in Russian and Chinese and to illustrate the theory with examples. As a result, both languages show similarities and differences in the structure and semantics of the paired compound words, primarily due to typological differences.

The article is addressed to researchers-philologists interested in comparing Russian and Chinese languages, as well as students studying these two languages. Knowing the word-formation rules and types of the paired compound words makes it easier for students to master new words, especially the compound words not recorded in explanatory dictionaries.
\end{abstract}

Keywords: The compound words, The paired words, Types of the paired words, Comparison, Chinese, Russian.

\section{INTRODUCTION}

In the Russian language, the paired compound words are compound words consisting of two components connected by synonymous (путь-дорога 'way, road'), associative (руки-ноги 'hands and feet (limbs)'), or antonymic (туда-сюда 'hither and thither') relations [1]. In the Chinese language, similar words of this type are compound words of the compositional type formed in the way of compounding. They consist two components, the meaning of which are synonymous (根 'base' + 本 'base' $\rightarrow$ 根本 'base'), or relativistic (江 'river' + 山 'mountain' $\rightarrow$ 江山 'nature, territory'), or antonymic ( 呼 'exhale' + 吸 'inhale' $\rightarrow$ 呼吸 'breathe, breath') [2].

In this article, we will analyze types of the paired compound words in Russian and Chinese, as well as their similarities and differences.

\section{TYPES OF THE PAIRED COMPOUND WORDS ACCORDING TO THE RELATIONS BETWEEN THEIR COMPONENTS IN RUSSIAN AND CHINESE}

In the Russian language the regular relations between the components of the paired compound words are: synonym, antonym and association. Accordingly, there are three types of the paired compound words [1]:

Synonymous type: узнать 'learn' + cnросить 'ask' $\rightarrow$ узнать-спросить 'to know, to ask'; нежданнылй 'unexpected' + негаданный 'unguessed' $\rightarrow$ нежданный-негаданный 'unexpected, unguessed'; сильный 'strong' + могучий 'mighty' $\rightarrow$ сильный-могучий 'strong-mighty'.

Antonymic type: левылй 'left' + nравыцй 'right' $\rightarrow$ левылй-правый 'left and right'; туда 'there' + сюда 'here' $\rightarrow$ туда-сюда 'there and here (back and forth)'; купля 'purchase' + продажа 'sale' $\rightarrow$ купля-продажа 'purchase and sale'.

Associative type: 102 'south' $+o$ (the connecting vowel) + заnad 'west' $\rightarrow$ юго-заnad 'south-west'; paз 
'one' + два 'two' $\rightarrow$ раз-два 'one-two'; золото 'gold' + серебро 'silver' $\rightarrow$ золото-серебро 'gold-silver'.

Among them, in the Russian language, there are so-called the paired approximations of total semantics [3]. For example:

хлеб 'bread' + соль 'salt' $\rightarrow$ хлеб-соль 'bread and salt' (associative type): treat;

руки 'hands' + ноги 'feet' $\rightarrow$ руки-ноги 'hands and feet' (antonymic type): limbs;

внуки 'grandchildren' + правнуки 'great grandchildren' $\rightarrow$ внуки-правнуки 'grandchildren and great grandchildren' (associative type): offspring;

купля 'purchase' + продажа 'sale' $\rightarrow$ купля-продажа 'purchase and sale' (antonymic type): trade.

Similar words are also found in the Chinese language:

吃 'eat' + 喝 'drink' $\rightarrow$ 吃喝 'eat and drink' (associative type): nutrition;

父 'father' + 母 'mother' $\rightarrow$ 父母 'father-mother' (antonymic type): parents;

手 'hands' + 脚 'feet' $\rightarrow$ 手脚 'hands and feet' (antonymic type): limbs;

子 'sons' + 孙 'grandsons' $\rightarrow$ 子孙 'sons and grandsons' (associative type): offspring.

Gorelov V.I. in his work «Lexicology of the Chinese language» wrote about three subtypes of the compositional compound words in the Chinese language: generalizing type, synonymous type and antonymic type [3].

Words of the generalizing type in Chinese are combinations of two significant morphemes that represent objects or actions. Formed lexical units have a high degree of generalization. The original components of these words usually lose their lexical independence and seem to dissolve in the generalized meaning of a compound word.

Chinese philologists prefer to call the generalizing type associative type. For example, the philologist Sun Peijie believes that the category of the associative type should include all other paired compound words that are not synonymously or antonymously related, even if their components do not belong to the same semantic category [4].

Lexical units of the generalizing (associative) type form two morphological and semantic subtypes [3]:

The combination of two root words representing objects. In some cases, morphemes that are part of words of this subtype represent two specific concepts, while a compound word serves as a generic concept [3] For example:

Specific concepts: 刀 'sword' + 枪 'pike' $\rightarrow$ generic concept: 刀枪 'weapons';

Specific concepts: 草 'herbs' + 木 'trees' $\rightarrow$ generic concept: 草木 ‘vegetation’;

Specific concepts: 岁 'years' + 月 'months' $\rightarrow$ generic concept: 岁月 'time'.

The combination of two root words representing actions. As a result of generalization of the meanings of word-forming morphemes and their semantic reinterpretation, lexical units with object meaning appear [3]. For example:

Actions: 书 'write' + 记 'write' $\rightarrow$ object meaning: 书记 'secretary';

Actions: 见 'see' + 闻 'hear' $\rightarrow$ object meaning: 见闻 'awareness';

Actions: 会 'gather' + 议 'discuss' $\rightarrow$ object meaning: 会议 'meeting'.

The paired compound words of the synonymous type in the Chinese language are a combination of two root words that are in synonymous connections. They represent two items or two attributes (or qualities, or actions). The morphemes that form these words are identical or similar in meaning.

Synonymous words can be divided into three morphological and semantic subtypes [3]:

The combination of two root words representing objects. For example:

$$
\begin{aligned}
& \text { 妇 ‘woman'+ 女 ‘woman’ } \rightarrow \text { 妇女 ‘woman’; } \\
& \text { 房 ‘house' + 屋 ‘house' } \rightarrow \text { 房屋 ‘house’; } \\
& \text { 墙 ‘wall' + 壁 ‘wall’ } \rightarrow \text { 墙壁 ‘wall'. }
\end{aligned}
$$

The combination of two root words representing quality as a permanent feature of the object. For example:

$$
\begin{aligned}
& \text { 均 'equal' + 匀 'equal' } \rightarrow \text { 均匀 'equal'; } \\
& \text { 富 'rich'+ 足 'rich' } \rightarrow \text { 富足 'rich'; } \\
& \text { 寂 'quiet' + 静 'quiet' } \rightarrow \text { 寂静 'quiet'. }
\end{aligned}
$$

The combination of two root words that represent an action as a variable feature of the object. For example:

Action: 增 'add' + 加 'add' $\rightarrow$ a variable feature of the object: 增加 'add';

Action: 雕 'sculpture' + 塑 'sculpture' $\rightarrow$ a variable feature of the object: 雕塑 'sculpture'; 
Action: 管 'manage' + 理 'manage' $\rightarrow$ a variable feature of the object: 管理 'manage'.

It should be kept in mind that a copulative complex with synonymous components that duplicate each other is usually only a two-syllable version of a monosyllabic word (component) that is freely used in modern Chinese [5].

Complex lexical units of the antonymic type in Chinese are formed as a result of a combination of two morphemes that are in antonymic connections. They usually indicate two attributes (or qualities or actions), less often - two items. The combination of antonyms leads to a generalization of meanings and semantic transformation of the components of morphemes: a word with a different meaning appears, which also usually belongs to a different lexico-grammatical class. [3]

Lexical units with antonymic connections between their components are divided into three morphological and semantic subtypes [3]:

The combination of two root morphemes representing qualities as constant attributes of objects. For example:

$$
\begin{aligned}
& \text { 大 'big' + 小 'small' } \rightarrow \text { 大小 'value, size'; } \\
& \text { 长 'long' + 短 'short' } \rightarrow \text { 长短 'length'; } \\
& \text { 深 'deep' + 浅 'shallow' } \rightarrow \text { 深浅 'depth, }
\end{aligned}
$$
measure'.

The combination of two root words representing actions as variable features of objects. For example:

$$
\begin{aligned}
& \text { 买 'buy' + 卖 'sell' } \rightarrow \text { 买卖 'trade'; } \\
& \text { 呼 'exhale' + 吸 'inhale' } \rightarrow \text { 呼吸 'breath, }
\end{aligned}
$$
breathe';

$$
\text { 取 'take' + 舍 'throw' } \rightarrow \text { 取舍 'select'. }
$$

1. The combination of two root words representing objects. For example:

$$
\begin{aligned}
& \text { 儿 'son’ + 女 'daughter' } \rightarrow \text { 儿女 'children’; } \\
& \text { 天 'sky' + 地 'earth' } \rightarrow \text { 天地 'nature'; } \\
& \text { 父 'father' + 母 'mother' } \rightarrow \text { 父母 'parents'. }
\end{aligned}
$$

So, both in the Russian language and in the Chinese language, there are three connections between the components of paired words: synonymous, associative, and antonymic, which distinguishes three corresponding types of the paired words. In Chinese, the components of paired words mostly belong to the lexical and grammatical category of a noun, an adjective, or a verb. In the Russian language, we noticed from the examples that numeral words or adverbs can also serve as components of the paired words.

\section{DIFFERENCES AND SIMILARITIES BETWEEN THE PAIRED COMPOUND WORDS IN THE RUSSIAN AND THE CHINESE LANGUAGE}

E.V. Fomin in the «On essential parameters of the paired words of the Russian language» described the characteristics of paired compound words, in terms of different parameters: lexical-semantic, word order, grammar, etc. [1]. On the basis of his research we will compare the paired compound words in the Russian and the Chinese language, on the basis of following parameters:

Productivity: In the Russian language, the paired words are unproductive. However, in Chinese, the compositional model plays an important role in the formation of compound words. The number of compositional compound words takes the second place, only behind the compound words with a subordinate connection [7].

Spelling parameter: in Russian, parts of the paired words are written with a hyphen. For example, стежки 'stitches' + дорожки 'tracks' $\rightarrow$ стежки-дорожки 'stitches-tracks'. In Chinese, on the contrary, they are written without any signs: 智 'wisdom' + 慧 'wisdom' $\rightarrow$ 智慧 'wisdom'.

Grammatical parameter: in Russian, the original form of paired words can be a frozen grammatical form: (учить) уму-разуму '(learn) mind-to-mind' (singular noun in the dative case), but not $y_{м-р а з у м}$ (singular noun in the nominative case).

The components of paired words in Russian have the same grammatical meaning [1]. For example:

жил-был 'once upon a time':

жил 'lived' - past tense singular verb in the masculine gender

был 'was' - past tense singular verb in the masculine gender;

руки-ноги 'hands and feet (limbs)':

руки - noun in the nominative case in the plural

ноги - noun in the nominative case in the plural;

ест-пьёm 'eats and drinks':

ecm - verb in the present tense in the third person singular

пьёm - verb in the present tense in the third person singular.

There is no change in grammatical form in Chinese.

Lexical and semantic parameter: the paired words of the Russian language have a generalizing, abstract meaning [1]. For example, nуть-дорога indicates all the 
road. This moment is also real for the Chinese language: 骨 'bone' + 肉 'meat' $\rightarrow$ 骨肉 'kindred'.

Word order setting: the paired words in the Russian language usually have a fixed order of components: трали-вали 'idle talk', but not вали-трали. This is not absolute, in some cases, allowed the equivalent of the permutation: туда-сюда 'here and there (back and forth)' = сюда-mуда 'here and there (back and forth)'. The situation is the same in Chinese. Only some words of the synonymous type allow different order. They thus exist in two versions, forming as pairs of doublets. For example, 兵士 'soldier' = 士兵 'soldier'; 替代 'replace' = 代替 'replace'.

However, in some cases, after a permutation, there is a difference from the original form in meaning or application, it is not exactly equivalent to the original form. For example, the original form 健康 'healthy' has two meanings [7]:

(About human being) physiology normal, without defects and diseases;

(About the object or event) the condition is normal, without defects.

When rearranged, 康健 also has the meaning healthy, but it especially emphasizes the good condition in older people and is used in a much narrow context of speech:

\section{相别十几年，你老人家越发康健了。}

'I haven't seen you for more than ten years; you've been healthier and healthier.'

\section{CONCLUSION}

The paired compound words in two languages differ greatly from each other in many aspects. Based on the above analysis, we can draw the following conclusions:

Both in Russian and Chinese, the paired words usually consist of two morphemes and have a generalizing, abstract meaning. The order of components is fixed, but some exceptions are allowed. There are three types of paired words based on the connections between components: synonymous, associative, and antonymic. In addition, in both languages, there are so-called the paired approximations of total semantics.

In the Russian language,the paired words are written with a hyphen, as in the Chinese language are written together, without any signs.

In the Russian language, the paired words can be some frozen grammatical form. There is no change in grammatical form in Chinese.

\section{REFERENCES}

[1] E.V. Fomin, On essential parameters of the paired words in the Russian language, 2017. Information on

https://libweb.kpfu.ru/publication/papers/Baudouin/ Baudouin-2017-1/Baudouin-2017-1-278-280.pdf

[2] Qingxiang Zhang, Yan Liu, Introduction to modern Chinese, Shanghai University, 2008.

[3] V.I. Gorelov, Lexicology of the Chinese language, Prosveshchenie, Moscow, 1984.

[4] Peijie Song, Research on modern Chinese noun-noun compound words, Huazhong University of Science and technology, Ph. D. thesis, 2014.

[5] A.L. Semenas, Copulative type of communication in the vocabulary of modern Chinese, Moscow, 1973.

[6] Xiaohui Xiao, Semantic analysis of a class of juxtaposed compound words//Journal of Jinggangshan Normal University (philosophy and social science), 2003, No.3, pp. 49-52.

[7] The dictionary of the Chinese language, Information on https://www.zdic.net. 